The amount of dye eliminated shows us accurately the extent of impairment of the kidney. 'There is, moreover, no patliologic condition of the kidney in which there is an increased permeability to the drug. The amount of dye passed does not depend on the amount of urine in which it is passed; 4.0 per cent. has been recorered in 5 c.c. of urine.

423 Candler Building.

\section{A CASE OF CHRONIC PARALDEHYDISM *}

\author{
WILLIAM HART', M.D. \\ CARTHAGE, N. MLX.
}

'The infrequency of chronic paraldehydism warrants the report of this case. 1 know of but three other cases reported in literature. 'This patient first came unler my olservation in the psychopathic wards of the Philadelphia (ieneral Hospital under the services of Dr. F. $X$. Derrum, with whose kind permission this report is made possible. In these wards one has the opportunity of studying many cases of alcoloolic addictions, as well as morphin, laudanum, cocain and opium habits acquired by inclividuals. less frequently are seen patients with the craving for other drugs, as caffein, strychnin, chloroform and acetrnilid.

On account of the symptoms and nervous manifestations noted in this case, I was led to believe that it was due to some cumulative toxic action of some other inug than those classed in the above entegory. Close questioning, however, revenled that I was dealing with a case of chronic paraldehydism.

Paraldelyd is a product obtained by the action of dilute sulphuric or nitric acid on an aldelyd. It is a colorless liquid with an ethereal oflor and disagrecalle pungent taste. It is readily soluble in alcolonl, but Jess 80 in water. It is a relinble hypnotic and nervous selative. being almost equal in its soporific effects to chloral, though its action is less persistent nond requires a more frequent repetition in its administration than chloral. It causes a sensible fall in arterial pressure, but is not so depressing to the heart as is chloral. It strengthens and slows the hent action, instend of weakening it. It profluces a sound sleep which is refreshing to the patient. It is a useful lyppnotic in insomnin from various causes, particularly in fevers, manin and histeria. and has been used successfully ns nu antispasnodie in asthma and in the trentment of tetanus. lt las no analgesic properties. Its disadrantages are that it has to he given in coniparatively large doses and it has a disugrecible taste and odor. The dose of parnldelyd is from 20 minims to 2 fluidrams; but the latter quantity las frequently been exceeded without any ill effects. Very fW cases of poisoning resulting from this dirug are recordect. In one cuse on record the putient recovered from a dose of $31 / 2$. ounces after thirty-four hours of somnd sleep. (Mackenzic, Douglas, Isle of Man.)

Chronie paraldelivelisnt is infrequently secn. The iudividual presents it train of stmptoms mot unlike those olserved at times in delirium tremens. Tremulousness, restlessness, mental anxiety and agitation with incoherent speech are most frequently noted. IBmacintion, anemia, gastric derangements and cutaneous eruptions are also observed.

\section{REPOI'S OF CASB}

Patient,-J. R. 'T., white, Americun, nged 47, sulesmun, was adluitted to the hospital Oet. 15, 190!), with chiof compluint

- Read before the Iblladelplija Psychlutíc Soclety, Nov. 10, 1011. of insomnia and nervousness. He hal been using alcohol for a long time, but never to execss; used tobacco to excess. He lual $a$ brother in an insane asylum suffering from recurrent mania.

The patient dated his present trouble to five years beforo admission when he was in $n$ hospital for treatment for insommia, from which condition he lud suffered for tho past twenty-five years. While in the hospital he received 1 fluidram of paraldehyd at bedtime with the desired result of a sound sleep. After four Weeks' stay in the hospital le was discharged as cured of his insomin. For the next three years he abstained from the use of paraldehyd. The insomnia then recurred and he gradually began to resort ngain to this drug to allevinte slecplessness. At first l fludirnm sulliced to induce sleep, but gradunlly he increased the dosage until during the yenr previous to admission he became so enslaved to the drug that he took on the average of 2 fluidounces dajly to produce the desired hypnotic eflect. After each such dose he felt intoxicated, this being followed later by a state of contentment; a panorama of beautiful pictures und recollections of pleasunt things, long forgotten, passed through his mind in rapid succession; he felt exhilarnted and nppenred stronger. He had not noticed any ill effects from its use on the stomach but had observed a tendency toward looseness of the bowels. A sound sleep would generally follow the alministration of 6 or 8 fluidrams of the dring and on awakoning his hend would always be elear. Though his hands and feet perspired, yet they felt cold.

bxamination.-The patient was a small, stockily built white man apparently much older than his years. He was very restless and continually interrupted to ask questions. While in bed lee refused to lie down, but sat up and was forever taking notice of his enviromment. 1 lis face was erythematous, the small eapillaries were markedly dilated and there was a prominent cyanotic tinge to the facies. The nose land the appearance of an acne rosucen. The hair was thick and almost gray, skin warm and moist. His eyes were of medium size and reneted to light and accommodation. A prominent areus senilis was present. The vessels over the entire body showed evidence of an existing arterioselerosis. The bymph-grlands and muscles were normal. The patient showed a tine tremor of fingers, lips, tongue and fucial muscles, much more marked than is commonly seen in aleo. holies. The hands were cyanotic, fingers broad and clubbed. The buecal mucosa was congested. The tongue was dry. conted and fissured, large and centrally protruling with finc tremor: The teeth were in bad state of preservation. The chest was rounded and barrel-slinped. The skin over the thorax was mottled and showed some acne lesions. The lungs and heart were normal; the ubdomen flnbby and disteuded, liver and spleen were not palpable. Ophthalmoscopic exami. nation of the eyes, and exnmination of urine and blool proved negative.

(3) the evening of admission insommin was nurked. The patient slept but a half hour at " time, although woder the influence of powerful lypnoties, as the following which was repeated three times during the night:

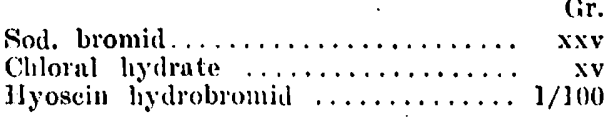

During the entire night he was restless nud constantly craved for a drink of paraldehyd. He drank large amounts of water and expectorated freely. The following night the same treatment was administered, but with very slight effect on the insommia. lle remnined in the hospital for one week and was dischurged with no pereptible improvement in his condition.

Age of Parents and Expectancy of Life of Children.-The expectancy of life of those born at the maturity of the parents is about fifty years, and at the extremes about lun that figure. Now, as the object of reproduction is to reproduce, births in these lnte yours are in a collective sense valueless.R. J. Ewart in liugenies lievicw. 